\title{
Zhou and Qin Ethical Culture and the Cultivation of Socialism Core Values
}

\author{
Jin-Yu HU \\ School of Humanity, Economy and Law of Northwestern Polytechnical University \\ Deputy director of Postgraduate Administration Department at Chang'an University
}

Keywords: Zhou and Qin Ethical Culture, Socialism core values, Cultivation.

\begin{abstract}
Zhou and Qin Ethical Culture is the basis and core of Chinese Culture which represents the source and orientation of traditional Chinese Culture. Investigation of the relationship between Zhou and Qin Ethical Culture and socialism core values is not only an important theoretical but also a practical issue. Applying the conviction ethic and responsibility theory of Zhou and Qin Ethical Culture as reference, could have strong inspiration and practical value for the cultivation values with the modern socialism as its core.
\end{abstract}

\section{Introduction}

Core value is known as the country, society and individual dominated value proposition. It does not exit originally and will not remain the same. The formation of core value requires an "advocated", "cultivation" and "practice” process. Whether core value can be accepted by populace and become a general consensus, depends on two aspects: 1) if it is compliant with the historical and cultural psychology of our nation, has a basis in the traditional culture, and reflects ethic characteristics; 2) if it is scientifically advanced, complied with the world trend, and reflects the orientation of advancement of our nation. Once these two aspects are met, core value will become a community consensus, and a force to unite the people and direct social progress. In the thirteenth group study among the members of the Political Bureau of CPC Central Committee, Vice President Xi indicated the importance of learning from the Chinese traditional cultural excellence, and promotion traditional Chinese national spirit with patriotism as the core of the inherent characteristics and Zeit Geist with reform and innovations as its core, with the emphasis on the relationship between creative continuation and development. Nowadays, how to cultivate socialism core value, and make it a community consensus is the new subject faced by the theories. This paper focuses on the investigation of the value orientation of Zhou and Qin Ethical Culture, to determine the status and role of "Zhou and Qin" in the cultivation process of socialism core values.

There are several understandings to the concept of "Zhou and Qin”. In this paper, the concept is adapted in the broader term, which means the investigation covers the ethical culture from Western Zhou dynasty, Spring and Autumn Period, to the revolution of Qin dynasty, and its long-term influence to the later generation.

\section{The Content and Characteristics of Zhou and Qin}

\section{Virtue Ethic of People in Zhou Dynasty}

The "moral value" of people in Zhou dynasty includes not only their belief, understanding and compliance in Heaven, World and Human, but also the integration of traditional morality, realistic morality and ideal morality. Politicized, ritual-musical and theorize are the characteristics of virtue ethic of people in Zhou dynasty. Since the Zhou dynasty has enthroned, great attention was placed on the construction of ethic culture mainly for stabilizing their political situation. While moral has been religion and religion has been moralized, People in Zhou also political zed the moral and moralized the political. The moral value of people in Zhou dynasty, represented by Lord Zhou, has trended to be more systematically theoretical, as belief and morality, political morality and family morality were integrated and become an important component of social ideology. In addition to 
this, the abstract ethical thought, notion and spiritual culture werealso turned into the concrete system of rites and music and behavioural norm that make them be in more predominant position in various realms of social life with enhanced functions. Zhou and Qin ethical cultural has not only penetrated into all aspects of the West Zhou dynasty, but also laid the foundation for the subsequent long-term development of Chinese culture to make it full of thick ethical colour and moral orientation.

The virtue value of people in Zhou dynasty has the following features: First of all, according to their ethical belief, universal destiny is the object of belief. People in Zhou dynasty's destiny view is inherited from Yin people's worship for ancestors and deities. However, the core of their destiny view has been gradually shifted to a common, impartial and absolute moral imperative that is the belief of universal destiny of a certain moral will. Secondly, the ethical belief of people in Zhou shows that virtue is the behavior principle. In the Zhou dynasty, people's virtue view is closely related with the belief of universal destiny. They believe that Heaven will not offer great missions to the immoral people. Lastly, the symbolic form of ethical belief of people in Zhou dynasty is rites and music. People in Zhou dynasty used rites and music to express their belief in universal destiny and virtue spirit, and its symbolic form to normative order and communicate order beyond the shore.

\section{Responsibility Ethic of People in Qin Dynasty}

Responsibility ethic is the main kinds of ethics in social culture of Qin dynasty. Wang Guowei indicated that people in Qin dynasty had abandoned both of the virtue spirit and the universal destiny related ethical belief, as they had placed much value on profit and power. According to Max Weber, the war of plundering between the warlords during the period of Spring and Autumn Warring States has led to the renationalization of economic policy, political system and military organization of Qin dynasty.

Characteristics of Qin of the ethics of responsibility: first of all, the aim of Qin of the ethics responsibility is enriching the country. In Qin Dynasty, the belief of which morality is the most is completely disappeared, instead of material interests. Secondly, the action criterion of the Qin is rational. Rulers of the Qin bureaucratic believed that achieve economic, military and enriching the "commonweal" objective by rational means. Embodiments of the responsibility ethics of Qin Dynasty is spell potential. Qin rational legal, administrative, fiscal system of the Qin Dynasty is realized through the form of magic potential.

Summary of the two type of ethical culture characteristics of the Zhou and Qin and can be seen beliefs, ethics and responsibility ethics are different. One pay attention to personal interest in reality, the other emphasize public interest in the future ;One consider moral spirit is Important, but other value the rational spirit. If rationality and virtue, rigid and flexible can is complementary then the society can achieve a perfect result. The essence of Zhou Qin's ethics culture is to Integrate both in Chinese traditional culture, and then it is the important content of the modern society.

\section{The Value Orientation of Zhou and Qin Ethical Culture}

The content and value orientation of Zhou Qin's ethical culture are interdependence and inter-infiltration. It is impossible to explain the value orientation without the content of the culture, and the content will be useless without the existing of value orientation.

\section{The Value Orientation of Zhou Ethical Culture}

For Zhou's ethical culture, "filial piety" is the core part of ethical regulations. According to Zhou Gong, the ethical thoughts of "matching heaven with virtue" and "moral respecting and people protection" are proposed. Human-oriented, respecting virtues to the ritual is the basic characteristics of Zhou. All the characteristics are reflected in Confucian classics which include "the Book of Changes", "the Book of History”, "the Book of Songs”. After the construction of the Zhou dynasty, the governing method origins of Shang dynasty which based on the lineage, on the other hand, 
implement the cultural theme of conversion. Zhou "reform" is the first performance in order to establish the patriarchal clan system. In order to maintain the clan unity, temple worship system is also created. The moral value orientation of the culture of Zhou dynasty is also reflected in the culture of artifacts, such as bronze ware. Bronze ware, as a kind of material culture, is the externalization and materialization of contrivers' cultural mentality. Bronze reed purposes, reflect that the Zhou people adapt to worship ancestors and create ethical culture form. The words on some of the bronze wares have ethical significance. Also like the phoenix worship, representing the authority in the political and ethical culture consciousness.

\section{The Value Orientation of Qin Responsibility Ethics}

From the aspect of ideational culture, the value orientation and standard of behavior of Qin are according to the secular behaviors and less affected by the western Zhou dynasty music cultural and constraints. People were concerned about the production and conduct operations which closely related to daily life interests, but not paid attention on the waste of righteousness, reed of ups and downs, and improve the moral. From the perspective of behavior culture, from the Qin dynasty founded, to unify the whole country, Qin people took delight in talking about the agricultural battle, attack and so on. From the perspective of system, the utilitarianism and practical are also the value orientations of Qin people. Many of the institutional innovations have profound influence and have the historical milestone significance. Especially after Qin Shi Huang unified China, the government abolished the system of efferent, carried out the system of prefectures and counties, the whole country is divided into 36 prefectures and the prefecture has counties. Key officials of the central and local governments shall be appointed or removed by the emperor, but not hereditary. Since then, China's political system is made to imperial, and emperor could replace the king.

\section{To Cultivate the Socialist Core Values by Drawing Lessons from the Ethical Culture Essence of Zhou and Qin}

\section{To be of the Same Virtues like Zhou and Qin Ethical Culture to Promote Social Harmonious Development}

The socialist core values propose Prosperity, Democracy, Civilization and Harmony. Getting along with others is a part of Harmony. And it is a quite important part. To explore the reason, to get along well with others is the basis of social harmony. The society will be in harmony only when people are friendly to others. However, nowadays, because of the benefits, most people expand their desires. Then they become more and more indifferent. But the ethical requirement of Zhou is to realize the great virtues and magnificent achievements, which indicates perfectly selflessness and human-nature-integration. The Great Virtues and Magnificent Achievements, first and foremost, are to bring up everything around the world. Governors ought to pay more attention to humans' values rather than the value of wealth. To gather and develop talented ones by wealth lays the foundation of domination. Secondly, it is the selfless virtue. Meanwhile, it is the virtue human-nature integration. That is, the great enterprise is the externalization of the flourishing virtues of people. Moreover, great enterprises tend to be undertaken by ones of flourishing virtues. So, in fact, the process of realizing The Great Virtues and Magnificent Achievements is to further improve people's virtues in the process of helping others succeed. It is also the achievement of self-transcendence, with much spirit of dedication. The spirit is still very important nowadays. Therefore, we should give Being of the Same Virtues wide publicity. Because that this spirit is undoubtedly an effective remedy to deal with social problems like egoism and moral indifference and so all. And mind is the first step to deal with problems.

\section{To Carry Forward the Thought of Integrity, and to Strengthen Moral Construction of Citizens}

Nowadays, to foster the socialist core values have become the tendency. We must carry forward the traditional virtues of Zhou and Qin ethical culture-Morality as the center. Also, we must get 
citizens know about that they just and loyal patriotism and integrity are excellent Chinese traditional virtues through more than two thousand years. We should inherit and carry forward in this period setting.

The subject nature of ethical requirements proposed by Zhou people is Ming De. The main content contains complete sincerity, faithfulness and humility. To be specific, from the perspective of human-nature relationship, Ming De means complete sincerity. From the point of human-human relationship, Ming De indicates faithfulness, which is the basis of connect among people, the way to get help from others, and the foundation of career success. And from the view of human-oneself relationship, Ming De refers to humility. Morality as the center of Zhou Qin ethical culture worth us inheriting and advancing. In the new era, as for citizens, integrity is no longer limited to the moral level. It has developed into the socialistic moral requirement towards citizens. Furthermore, the integrity functions as the prompt to all kinds of dishonest phenomena existing nowadays. It can provide thought resources to build the integrity of citizens.

\section{To Discipline Citizens' Behaviors by Drawing Confucian Thought from Zhou Qin Ethical Culture}

The Confucian thought of Zhou Qin ethical culture guides and restrains citizens' behaviors, with the principles from two sides, one is to guide people by filial thought, the otheris to restrain peoples' behaviors by feudal code of ethics. The common point of the two sides is that they both lay emphasis on thoughts, which are used to lead people. Today, socialist core values are being built. We can draw and carry forward the Confucian thought. Also, we should lead people's mind, and then to discipline behaviors of citizens.

Ethical elements in Chinese traditional culture which in the development of the course is from the beginning of the week of the beginning of the formation of ideological change, that. The ideal of ethical of the Zhou Qin's ethics culture is mainly reflected in the combination of the moral ideal and the form of ceremony. The Duke of Zhou created of the civilization ritual, the ritual of civilization of China got a great development in the Western Zhou dynasty. In fact, ritual is institutionalized and ethical spirit and is formed in the process of human civilization. It has the function of expressing emotion and the faith, and has the function of moral standard. The Zhou Dynasty etiquette is very complicated, but it is the external expression of people's inner feelings, ideals and beliefs, and so on. The rites of the Zhou Dynasty which are too complex and preach superstition, hierarchical and patriarchal historical limitations, but It has the meaning of inspiration and reference of making the abstract and concrete moral spirit standardized and institutionalized and providing methodology for people. Today we draw on the ethical culture of Zhou and Qin Dynasties thought of ritual to ethics to guide the public, to constrain the public with the rites, by improving the social overall appeal and centripetal force. To make people take the initiative to avoid the crime of shame. This is the law that is the inner moral constraints. It has practical value to construct a harmonious society, through the internal restraint, external legal sanction and the behavior of the public standard.

With the understanding of the traditional culture is gradually moving towards in-depth, the Chinese Communist Party must guide the people to establish cultural self-confidence and consciousness, and pay attention to the value of the traditional culture. The people's warmth and respect for the traditional culture will be gradually internalized to deep rooted emotions, which as the core values of the identity of the foundation. It will be a long and arduous task, which is to strengthen the traditional culture education and to enhance the understanding of the traditional culture in practice. Of course, the purpose of promoting the traditional culture of excellence is not to restore ancient ways, but to innovation". Only by combining the excellent traditional culture and the contemporary advanced culture of China, the traditional cultural values and the socialist values are combined, creating the socialist core values of Chinese traditional culture and higher than that of Chinese traditional culture, so that the core values of socialism can not only have a profound historical and cultural background, but also the modernity. And can not only realize the inheritance, innovation, development and sublimation of the traditional culture, but also fully embody the essence of socialism. 


\section{References}

[1]Analects[M].Shanghai Ancient Books Press. 1987

[2] Xuncius[M].Shanghai Ancient Books Press. 1986

[3]Li sheng. Note of Changes[M].Changsha: Hunan Education Press.2004

[4]Max weber. Konfuzianismus and Taoismus[M]. Guangxi Normal University Press.2010

[5]E.shils. Tradition[M]. Shanghai People's Press.2014

[6]Hou Wailu. On the Social History of Ancient China[M]. Hebei EducationPress.2000

[7]Pang Bo and Ge Xinyang. An Analysis of filial ethics and its meanings in the Analects of Confucius[J]. Intelligence, 2014, (6)

[8]The Book of Rites[M].Shanghai Ancient Books Press. 1987

[9] Li jianseng."The Analects" of Confucian's Morality and Behavior "four negative sentences" can refer to the signifier of negative expansion [J].Explore the possibility of a classical Chinese culture with Western thinking about interpretation of the logical semantics,2016(12)

[10]Feng feilong. The Confucian Filial Ethics: Its Modern Values and Interpretations [J].Explore the possibility of a classical Chinese culture with Western thinking about interpretation of the logical semantics,2016(12)

[11] Li wei. On the ecological ethics culture of Zhou Qin and Its Contemporary Value [J].Morality and Civilization.2016(4)

[12]Lin cunguang. How to recognize and understand the historical meaning of the five virtues [J].Journal of the History of Political Thought, 2016(4) 